\title{
Fate of LCFA in the co-digestion of cow manure, food waste and discontinuous addition of oil
}

\author{
L. Neves, R. Oliveira, M.M. Alves* \\ IBB - Institute for Biotechnology and Bioengineering, Center of Biological Engineering, University of Minho, \\ Campus de Gualtar, 4710-057 Braga, Portugal
}

\section{A R T I C L E I N F O}

Article history:

Received 26 May 2009

Received in revised form

7 August 2009

Accepted 10 August 2009

Available online 15 August 2009

\section{Keywords:}

Cow manure

Anaerobic digestion

Food waste

Long chain fatty acids

\begin{abstract}
A B S T R A C T
Different concentrations of oily waste were added in a discontinuous mode and recurrently to anaerobic continuous stirred tank reactors fed with cow manure and food waste. Four continuous stirred tank reactors were run in parallel. A control reactor (R1) received no additional oil and R2, R3 and R4 received increasing concentrations of oil in two different experimental approaches. First, the lipids composition was forced to change suddenly, in three moments, without changing the total chemical oxygen demand (COD) fed to the reactors. The only long chain fatty acid (LCFA) detected onto the R1 solid matrix was palmitic acid (C16:0). Nevertheless in the solid matrix of R2, R3 and R4 C16:0 and stearic acid were detected. For occasional increase in the oil concentration up to $7.7 \mathrm{gCOD}_{\text {oil }} / \mathrm{L}_{\text {reactor }}$ (55\% $\left.\mathrm{Oil}_{\mathrm{COD}} / \mathrm{Total}_{\mathrm{COD}}\right)$ no statistical differences were detected between the reactors, in terms of methane production, effluent soluble COD, effluent volatile fatty acids and total and volatile solids removal. Therefore this experiment allowed to conclude that cow manure-food waste co-digestion presents sufficient buffer capacity to endure solid-associated LCFA concentration up to 20-25 gCOD-LCFA/kgTS.

In a second experiment higher concentrations of oil were added, raising occasionally the concentration in the reactors to $9,12,15$ and $18 \mathrm{gCOD}_{\text {oil }} / \mathrm{L}_{\text {reactor. }}$ All pulses had a positive effect in methane production, with the exception of the highest oil pulse concentration, that persistently impaired the reactor performance. This experiment demonstrates that threshold values for LCFA and C16:0 accumulation onto the solid matrix, of about 180-220 gCOD-LCFA/kgTS and 120-150 gCOD-C16:0/kgTS, should not be surpassed in order to prevent persistent reactor failure, as occurs in some full scale co-digestion plants.
\end{abstract}

(c) 2009 Elsevier Ltd. All rights reserved.

\section{Introduction}

Several organic wastes are treated today in co-digestion processes together with manure (Weiland, 2004). The biogas yield from raw manure alone is only $20-30 \mathrm{~m}^{3} /$ ton and the operation of the plant is only economically feasible when the biogas yield is higher than $30 \mathrm{~m}^{3} /$ ton (Lindboe et al., 1995). Codigestion of manure with biodegradable waste appears as a robust process technology that can increased by $80-400 \%$ the biogas production in anaerobic biogas plants (Braun et al., 2003; Weiland, 2004), like food waste. Although co-digestion is an established and applied process, it is important to understand how the changes in the composition will affect the overall process. Food waste, composed by carbohydrates, cellulose, proteins, and lipids, can be highly variable depending on their sources and are not homogeneous in their day-by-day composition. Among the food components, lipids degradation still requires a deeper understanding. It is

\footnotetext{
* Corresponding author. Tel.: +351 253604 417; fax: +351 253678986.

E-mail address: madalena.alves@deb.uminho.pt (M.M. Alves). 0043-1354/\$ - see front matter @ 2009 Elsevier Ltd. All rights reserved. doi:10.1016/j.watres.2009.08.013
} 
realistic to consider possible transient, occasional, accidental or even on purpose increase in the lipid content of a food waste stream in a real context.

Lipids as substrate or co-substrate for anaerobic digestion processes constitutes an important issue due to the higher theoretical methane yield $\left(0.99 \mathrm{LCH}_{4} / \mathrm{g}\right)$ as compared to carbohydrates $\left(0.42 \mathrm{LCH}_{4} / \mathrm{g}\right)$ and proteins $\left(0.63 \mathrm{LCH}_{4} / \mathrm{g}\right)$, at standard temperature and pressure conditions (Alves et al., 2009). In this context, lipid-rich wastes can be regarded to have a large potential as a renewable energy source (Hansen et al., 1999). Nevertheless, in practice, the anaerobic digestion of lipids is often hampered as the theoretical methane production is not easily achieved. Frequently, the most reported problem is the failure of the system due to the presence/accumulation of the long chain fatty acids (LCFA), ensuing the lipids hydrolysis. LCFA have been reported as inhibitory/toxic to microorganisms even at low concentrations (Hanaki et al., 1981; Angelidaki and Ahring, 1992; Rinzema et al., 1994). More recently it was reported that LCFA inhibition was reversible. The observed transient inhibition was partially assigned to transport limitation, due to LCFA adsorption, instead of exclusively to metabolic phenomena (Pereira et al., 2004, 2005). Adsorption of LCFA is a wide reported phenomenon in the anaerobic digestion processes and is frequently the reason appointed to process failure (Miranda et al., 2006; Hwu et al., 1998; Cirne et al., 2007). Nonetheless, there are examples of successful anaerobic digestion of lipids in the literature. Li et al. (2002) reported that food wastes containing high lipids content, ranging from $8 \%$ to $40 \%$ by adding salad oil and lard of pork, were effectively degraded by high solids co-digestion process and over $85 \%$ of the lipids content was degraded. Ahring (2003) reported that the addition of $5 \%$ fish oil to a manure digester increased twofold the methane production per volume of feed. Recently, Nielsen and Ahring (2006) also showed that the addition of oleate pulses to thermophilic reactors treating mixtures of cattle and pig manure had a stimulating effect on the overall process.

In a previous work (Neves et al., 2009a), pulses of oily waste from a canned fish processing industry were added to mesophilic $\left(37^{\circ} \mathrm{C}\right)$ continuous stirred tank reactors with hydraulic retention time of 15 days fed daily with cow manure and food waste. Concentrations up to $15 \mathrm{gCOD}_{\text {oil }} / \mathrm{L}_{\text {reactor }}$ had a positive effect in methane production, whereas after a sudden addition of oil at $18 \mathrm{gCOD}_{\text {oil }} / \mathrm{L}_{\text {reactor }}$ a decay in methane production was observed, which persisted for a long time, suggesting an irreversible inhibition in the time scale of the experiment. This is extremely important as far as the co-digestion of lipids is concerned. Prevention of inhibition by LCFA rather than recovery after inhibition should be the right operational strategy to manage the full potential of methane production from lipids in full scale continuous anaerobic digestion plants.

So far, the exact behaviour of LCFA in co-digestion processes is not well understood. Inhibitory LCFA concentrations, ratio between solid phase-associated LCFA and methane production or/and fate of individual LCFA in codigestion processes with lipids, are issues that demand additional research efforts. The present study focus on assessing the individual profiles of LCFA associated to the solid phase of four reactors fed with cow manure and food waste, in two different approaches: First, the lipids composition was forced to change suddenly in three moments without changing the total chemical oxygen demand (COD) fed to the reactors. Secondly, pulses of lipids were added, raising the concentration in the reactors up to 9, 12, 15 and $18 \mathrm{gCOD}_{\text {oil }} / \mathrm{L}_{\text {reactor. }}$ Lipid concentration was manipulated by adding oily waste from a canned fish industry. One of the reactors was used as control and was devoid from the oily waste during both experiments. The ultimate goal was to determine the specific amount of LCFA that can be adsorbed into the solid phase (expressed as mg COD-LCFA/gTS) without compromising the process stability of a co-digestion anaerobic plant based on cow manure and food waste.

\section{Materials and methods}

\subsection{Substrates}

Three substrates were used in the anaerobic co-digestion process. (i) Cow manure, collected in a dairy farm in the suburbs of Braga (Portugal) and stored in a refrigerator $\left(4^{\circ} \mathrm{C}\right)$ until use to minimize the decomposition of substrate; (ii) Food waste, which was a composite sample (one week based) from the waste produced in the canteen of the University of Minho, located in "Campus de Gualtar", Braga, Portugal. It was crushed to $1-3 \mathrm{~mm}$ particle size and stored at $4{ }^{\circ} \mathrm{C}$ during 5 days, until the end of the collecting process. Then it was mixed and stored at $-18^{\circ} \mathrm{C}$; (iii) Oily waste collected in a canned fish processing industry was used to simulate the variation of lipids content. The characteristics of each substrate are presented in Table 1.

\subsection{Reactor start-up}

Four 5-L mesophilic continuous stirred tank reactors with hydraulic retention time of 15 days were fed with cow manure and food waste. The digesters were inoculated with the effluent from a stable laboratory mesophilic anaerobic digester fed with cow manure and food waste. The biogas flow rate generated was measured by a Ritter Milligascounter (Dr. Ing. Ritter Apparatebau GmbH, Bochum, Germany). After a stable operation of the four reactors, for 48 days, the experiments with occasional feeding of fat were initiated.

\subsection{Experimental plan}

Two sets of experiments with addition of different lipid concentrations were performed. In both experiments, the feed to the four reactors had a ratio of cow manure and food waste of approximately 1:1, either in COD or TS basis. The organic loading rate of the four reactors was $4.6 \pm 0.1 \mathrm{gCOD} /\left(\mathrm{L}_{\text {reactor }}\right.$ day). The lipid content was changed by adding pulses of oily waste to three of the four reactors fed with the mixture cow manure/food waste as depicted in Table 2.

One of the reactors (R1) was used as control and was devoid from the oily waste during the both experiments. The feed composition was changed on specific days as follows. In the first experiment, the oil composition was forced to change suddenly in three moments of the reactors operation. The 
Table 1 - Characterisation of cow manure, food waste and oily waste used in the continuously stirred tank reactors

experiments.

\begin{tabular}{lccc} 
Substrate & Cow manure $(\mathrm{g} / \mathrm{L})$ & Food waste $\left(\mathrm{g} / \mathrm{kg}_{\text {waste }}\right)$ & Oily waste $(\mathrm{g} / \mathrm{kg}$ waste $)$ \\
\hline $\begin{array}{l}\text { Chemical oxygen } \\
\text { demand (COD) }\end{array}$ & $39 \pm 8$ & $327 \pm 73$ & $2690 \pm 61$ \\
Total solids (TS) & $28 \pm 5$ & $266 \pm 1$ & $971 \pm 5$ \\
Volatile solids (VS) & $21 \pm 4$ & $254 \pm 7$ & $972 \pm 4$ \\
Fat content & ne & $20 \pm 8$ & $877 \pm 32$ \\
Long chain & Cow manure (gCOD/kgTS) & Food waste (gCOD/kgTS) & Oily waste (gCOD/kgTS) \\
$\quad$ & & & \\
fatty acids (LCFA) & $3 \pm 1$ & 0 & $19 \pm 1$ \\
Palmitic acid (C14:0) & $14 \pm 4$ & $14 \pm 4$ & $260 \pm 7$ \\
Palmitoleic (C16:0) & 0 & 0 & $27 \pm 1$ \\
Stearic acid (C18:0) & $26 \pm 9$ & $6 \pm 2$ & $75 \pm 2$ \\
Oleic acid (C18:1) & 0 & $16 \pm 5$ & $891 \pm 17$ \\
Linoleic acid (C18:2) & 0 & $8 \pm 2$ & $790 \pm 33$ \\
\hline
\end{tabular}

ne: Not evaluated; Data are expressed as mean \pm standard deviation of five replicates.

total COD fed to the system was approximately constant, even when sudden increases of oil concentration were imposed, meant that the amount of cow manure and food waste fed had to decrease in the moments of oil addition. Nevertheless, the ratio cow manure/food waste was still equal to 1 in a TS basis. After the first experiment the reactors operated in batch mode for 39 days. Afterwards, the cow manure/food waste feed re- started. In the second set of experiments, in reactors R2, R3 and R4, pulses of oil were applied, raising the concentration up to $18 \mathrm{gCOD}_{\mathrm{Oil}} / \mathrm{L}_{\text {reactor }}$ after pulse feeding. Specifically, six similar pulses of oil were added to R2, R3 and R4. A 7th pulse, with a higher quantity of oily waste compared to the first six pulses, was also added to R2, R3 and R4. From day 204 on, R4 did not receive any more inputs of oily waste, on account of

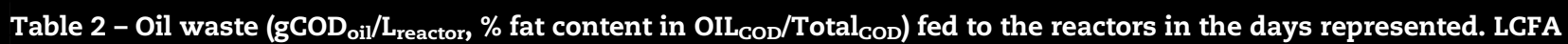
concentration (gCOD/kgTS) immediately after the feeding in each reactor calculated due to the oily waste addition.

\begin{tabular}{|c|c|c|c|c|c|c|c|c|c|c|}
\hline & Day & & Oily waste & Oil $_{\mathrm{COD}} /$ Total $_{\mathrm{COD}}(\%)$ & & & CFA (g & $\mathrm{D} / \mathrm{kgT}$ & & \\
\hline & & & $1 \mathrm{~g} C \mathrm{O}$ & & C14:0 & C16:0 & $\mathrm{C} 16: 1$ & C18:0 & C18:1 & C18:2 \\
\hline & 49 & R1 & 0 & 0 & 0 & 0 & 0 & 0 & 0 & 0 \\
\hline & & R2 & 0.4 & 6 & 0 & 1 & 0 & 0 & 4 & 3 \\
\hline & & R3 & 0.6 & 9 & 0 & 2 & 0 & 0 & 6 & 5 \\
\hline घี & & R4 & 0.8 & 13 & 0 & 3 & 0 & 1 & 9 & 8 \\
\hline ¿ & 56 & R1 & 0 & 0 & 0 & 0 & 0 & 0 & 0 & 0 \\
\hline ब्र & & R2 & 1.6 & 25 & 0 & 5 & 0 & 2 & 18 & 16 \\
\hline$\ddot{\omega}$ & & R3 & 2.4 & 38 & 1 & 9 & 1 & 3 & 31 & 27 \\
\hline 密 & & R4 & 3.3 & 51 & 1 & 11 & 1 & 3 & 36 & 32 \\
\hline & 84 & R1 & 0 & 0 & 0 & 0 & 0 & 0 & 0 & 0 \\
\hline & & R2 & 3.6 & 36 & 1 & 13 & 1 & 4 & 45 & 40 \\
\hline & & R3 & 5.4 & 46 & 2 & 20 & 2 & 6 & 68 & 61 \\
\hline & & R4 & 7.7 & 55 & 2 & 28 & 3 & 8 & 95 & 85 \\
\hline & $148^{\mathrm{b}}, 168^{\mathrm{b}}, 176^{\mathrm{b}}$ & R1 & 0 & 0 & 0 & 0 & 0 & 0 & 0 & 0 \\
\hline & $183^{b}, 190^{b}, 197^{b}$ & R2 & 9.0 & 60 & 2 & 31 & 3 & 9 & 104 & 94 \\
\hline & & R3 & 12.0 & 65 & 3 & 39 & 4 & 11 & 137 & 121 \\
\hline$\tilde{\Xi}$ & & R4 & 15.0 & 70 & 4 & 50 & 5 & 14 & 170 & 151 \\
\hline $\overrightarrow{\mathrm{d}}$ & 204 & R1 & 0 & 0 & 0 & 0 & 0 & 0 & 0 & 0 \\
\hline$\stackrel{x}{e}$ & & R2 & 12.0 & 65 & 3 & 39 & 4 & 11 & 137 & 121 \\
\hline ర్డ & & R3 & 15.0 & 70 & 4 & 50 & 5 & 14 & 170 & 151 \\
\hline త্ & & R4 & 18.0 & 74 & 4 & 60 & 6 & 17 & 207 & 183 \\
\hline & $211^{\mathrm{c}}, 218^{\mathrm{c}}, 225^{\mathrm{c}}$ & R1 & 0 & 0 & 0 & 0 & 0 & 0 & 0 & 0 \\
\hline & & R2 & 12.0 & 65 & 3 & 39 & 4 & 11 & 137 & 121 \\
\hline & & R3 & 15.0 & 70 & 4 & 50 & 5 & 14 & 170 & 151 \\
\hline & & R4 & 0 & 0 & 0 & 0 & 0 & 0 & 0 & 0 \\
\hline
\end{tabular}


the detected methane production decay. However, R2 and R3 received three more pulses of oily waste, each one equal to the 7 th pulse concentration.

\subsection{Analytical methods}

COD, pH, total solids (TS) and volatile solids (VS) were performed according to Standard Methods (APHA et al., 1989).

The total fat content was extracted with diethyl ether in a Soxtec System HT2 1045 extraction unit produced by Tecator (Official Methods of Analysis 2003.05, 2007).

Methane content of the biogas was measured by gas chromatography using a Porapack Q (180-100 Mesh) column, with $\mathrm{He}$ as carrier gas at $30 \mathrm{~mL} / \mathrm{min}$ and a thermal conductivity detector. Temperatures of the detector, injector and oven were $110^{\circ} \mathrm{C}, 110^{\circ} \mathrm{C}$ and $35^{\circ} \mathrm{C}$, respectively.

VFA (acetate, propionate, iso-butyrate and n-butyrate) were determined by high-performance liquid chromatography using a Chrompack column $(300 \times 6.5 \mathrm{~mm})$ and a mobile phase of sulphuric acid $5 \mathrm{mM}$ at $0.7 \mathrm{~mL} / \mathrm{min}$. The column was set at $60^{\circ} \mathrm{C}$ and the detection was by spectrophotometry at $220 \mathrm{~nm}$.

LCFA (lauric (C12:0), myristic (C14:0), palmitic (C16:0), palmitoleic (C16:1), stearic (C18:0), oleic (C18:1) and linoleic (C18:2) acids) analyses were done as described in Neves et al., 2009b. The liquid and solid matrix samples were submitted to a similar procedure. After centrifugation, for the liquid samples, once homogenized, $2 \mathrm{~mL}$ were transferred into glass vials. For the solid samples, a defined amount was transferred to the glass vials and dried for $12 \mathrm{~h}$ at $85^{\circ} \mathrm{C}$, the content of the vial was weighed. Free fatty acids present in the samples were esterified with HCl:1-Propanol $(1.5 \mathrm{~mL})$ and extracted with dichloromethane $(2 \mathrm{~mL})$. The mixture was digested at $100{ }^{\circ} \mathrm{C}$ for $3.5 \mathrm{~h}$. Quantification was made in a gas chromatograph system (CP-9001 Chrompack) equipped with a flame ionization detector. LCFA were separated using an eq. CP-Sil $52 \mathrm{CB}$ $30 \mathrm{~m} \times 0.32 \mathrm{~mm} \times 0.25 \mu \mathrm{m}$ column (Teknokroma, Tr-wax), with $\mathrm{He}$ as the carrier gas at $1.0 \mathrm{~mL} / \mathrm{min}$. Temperatures of the injection port and detector were 220 and $250{ }^{\circ} \mathrm{C}$, respectively. Initial oven temperature was $50^{\circ} \mathrm{C}$ for $2 \mathrm{~min}$, with a $10^{\circ} \mathrm{C} / \mathrm{min}$ ramp to $225^{\circ} \mathrm{C}$ and a final isothermal for $10 \mathrm{~min}$.

\subsection{Biodegradability tests}

Biodegradability assays were assessed separately, with the food waste and cow manure. Methane production produced by food waste was followed after incubation in batch vials in the following conditions: $5 \% \mathrm{TS}, 1.35 \mathrm{gVS}_{\text {waste }} / \mathrm{gVS}_{\text {inoculum. The }}$ granular sludge used as inoculum was collected from an upflow anaerobic sludge blanket reactor treating a brewery effluent located in Oporto, Portugal. The use of granular sludge inoculum reduces the risk of over-acidification during batch, high solids, anaerobic digestion (Neves et al., 2004). After the introduction of the correct amounts of food waste and inoculum, a defined amount of an anaerobic basal medium was added under strict anaerobic conditions, in order to attain the desired solid content. The anaerobic basal medium was composed of cysteine - HCL $(0.5 \mathrm{~g} / \mathrm{L}), \mathrm{NaHCO}_{3}$ ( $3 \mathrm{~g} / \mathrm{L}$ ), with the $\mathrm{pH}$ adjusted to 7.0-7.2. Resazurin was added as an indicator of redox potential (Colleran et al., 1992). The vials were then incubated at $37^{\circ} \mathrm{C}$ with a stirring speed of $150 \mathrm{rpm}$, and the methane production was regularly measured by gas chromatography.

Methane production from cow manure was followed after incubation in batch vials supplemented with anaerobic basal medium in order to achieve $5 \%$ TS, without any extra inoculum source, using the method described above. The volume of methane produced was corrected to STP conditions. The results were expressed in terms of methane production in $\mathrm{m}^{3} \mathrm{CH}_{4} / \mathrm{kgVS}_{\text {initial }}$ and \% of methanisation, which corresponds to the \% of methane produced relatively to the biochemical methane potential $\left(0.350 \mathrm{~m}^{3} \mathrm{CH}_{4(\mathrm{STP})} / \mathrm{kgCOD}\right)$. All batch experiments were performed in triplicate.

\subsection{Statistical analysis}

Single factor analysis of variances (ANOVA) was used to determine if significant differences existed between results obtained under different experimental procedures. Statistical significance was established at a $P<0.05$ level.

\section{Results and discussion}

\subsection{Methane production and reactors performance in the first experiment}

Before the experiments, all four reactors achieved a stable performance in methane production. The values obtained for R1 were $0.25 \pm 0.05 \mathrm{~m}^{3} \mathrm{~kg} / \mathrm{VS}_{\text {added }}$ along with $0.21 \pm 0.05$, $0.22 \pm 0.05$ and $0.26 \pm 0.04 \mathrm{~m}^{3} / \mathrm{kgVS}_{\text {added }}$ for R2, R3 and R4, respectively, with no statistical differences $(P=0.09)$. The VFA concentrations were lower than $1.2 \mathrm{gCOD} / \mathrm{L}$ and the $\mathrm{pH}$ was stable between 7.7 and 7.9. The percentage of solids reduction in the four reactors was 46, 47, 48, 46 for TS and 66, 65, 67 and 64 for VS. The TS and VS concentrations were not statistically different among the reactors $(P=0.951$ and $P=0.549$ for $T S$ and VS, respectively). In the first set of experiments the $\%$ of oil varied between 6 and $55 \% \mathrm{Oil}_{\mathrm{COD}} / \mathrm{Total}_{\mathrm{COD}}$ in the feeding, but the total COD fed to the reactors was kept constant. The methane production fluctuated between 0.20 and $0.35 \mathrm{~m}^{3} /$ $\mathrm{kgVS}_{\text {added. }} \mathrm{R} 1$ attained an average value of $0.26 \pm 0.06 \mathrm{~m}^{3} \mathrm{CH}_{4} /$ $\mathrm{kgVS}_{\text {added }}$ and R2, R3 and R4 displayed similar behaviours with methane productions of $0.26 \pm 0.06,0.28 \pm 0.07$ and $0.29 \pm 0.04 \mathrm{~m}^{3} \mathrm{CH}_{4} / \mathrm{kgVS}_{\text {added, }}$ respectively. The methane production profile was very similar throughout all the experiment. Using ANOVA to analyse all the values of methane production obtained in the four reactors, no statistical differences were observed. Comparing the methane production of all four reactors no dissimilarity was detected due to sudden increase in the lipid content. The values attained are in accordance to literature on dairy cattle manure co-digestion with bio-waste (household sorted) in mesophilic continued stirred tank reactors $\left(0.2-0.3 \mathrm{~m}^{3} \mathrm{CH}_{4} / \mathrm{kgVS}_{\text {added }}\right)$ fed with $20 \%$ / $80 \%$ (in VS) bio-waste/cow manure (Paavola et al., 2006).

The fluctuation imposed in the feed composition, induced a transitory increase in the lipids COD up to $55 \%$ of the total COD fed (day 84, R4). Nevertheless, the operational response did not exhibit any sign of inhibition in terms of methane production. Inhibition by lipids in co-digestion processes was 
reported previously. For instance Carucci et al. (2005), reported that anaerobic co-digestion of pre-cooked food wastes along with the aerobic sludge from the food factory wastewater treatment plant (5\% TS) inhibited methanogenesis, probably due to the high content in lipids ( $13 \%$ of dry weight in the precooked food wastes) in batch studies. Those authors also reported that methanogenesis inhibition was overcome by long acclimation periods.

The methane content in the biogas produced in the first experiment was between 54-61\%, 54-64\%, 57-64\% and 55-63\% in R1, R2, R3 and R4, respectively. These values are somewhat higher than the ones reported (51-57\% of methane) by Paavola et al. (2006). The fluctuations imposed in the lipid content did not change the biogas production and the respective methane content. These results clearly indicate that cow manure buffer capacity was able to overcome lipids transient fluctuations that can occur in food waste.

The biodegradability assays performed for food waste and cow manure gave $0.29 \pm 0.01$ and $0.11 \pm 0.01 \mathrm{~m}^{3} \mathrm{CH}_{4} / \mathrm{kgVS}_{\text {initial }}$, corresponding to $56 \%$ and $18 \%$ of the theoretical methane potential respectively. The values obtained for cow manure are small, but comparable with reported literature values for dairy cattle manure. Möller et al. (2004) reported an ultimate methane yield for dairy cattle manure of $0.148 \pm 0.04 \mathrm{~m}^{3} \mathrm{CH}_{4} /$ $\mathrm{kgVS}$, whereas Hill (1984) found a value of $0.131 \mathrm{~m}^{3} \mathrm{CH}_{4} / \mathrm{kgVS}$. This may be explained by the fact that there are big differences in the feeding practice and productivity between dairy farms. Hence, cows fed on only roughage give lower yields than cows fed on both roughage and concentrates (Möller et al., 2004).

The daily methane production achieved was $3.02 \pm 0.58$, $3.06 \pm 0.70,3.02 \pm 0.70$ and $3.09 \pm 0.51 \mathrm{LCH}_{4} /$ day in R1, R2, R3 and $\mathrm{R} 4$, respectively. Considering the daily feed, the theoretical maximum methane production expected was $5.46 \mathrm{LCH}_{4} /$ day. This means that $55-57 \%$ of the theoretical methane production was achieved.

The percentage of solids reduction in the four reactors was $47,48,50,49$ for TS and 59, 59, 60 and 60 for VS. No statistical significant differences were detected in TS or VS removal
( $P=0.131$ and $P=0.857$, respectively) in all reactors, when compared to R1.

The swift lipid change in the feed did not promote any fluctuation in the COD and VFA profiles, since no significant differences were detected $(P=0.705$ for soluble COD and $\mathrm{P}=0.202$ for VFA). A soluble COD between 5 and $9 \mathrm{~g} / \mathrm{L}$ was measured throughout all the experiment in all the four reactors.

Acetic and propionic acids were the only VFA detected, with acetic acid counting for $75-100 \%$ of the total. However, the VFA content was always lower than 1.4 gCOD/L corresponding to a maximum of $15 \%$ of the soluble COD. Accumulation of VFA is often reported as the main reason for failure of food waste anaerobic digestion processes (Kim et al., 2004). This substrate is easily degraded by fermentative bacteria which generate large amounts of VFA lowering the $\mathrm{pH}$ thus inhibiting the methanogenic system and limiting the generation of $\mathrm{CH}_{4}$ (Vavilin et al., 2006; Bouallagui et al., 2004). None of these reported effects have been observed. The $\mathrm{pH}$ values were stable and always between 7.6 and 7.8 in the four reactors, during the all trial, evidencing once more the benefits of the co-digestion of food waste with transient/variable lipids concentration with cow manure.

\subsection{Methane production in the second experiment}

In the second set of experiment, the addition of oil as pulses increased largely the values applied in the first experiment (Table 2). The COD content of the feed suffered corresponding increases. In this experiment the highest oily waste concentration added as a pulse, $18 \mathrm{gCOD}_{\mathrm{oi}} / \mathrm{L}_{\text {reactor, }}$ (74\% $\mathrm{OIL}_{\mathrm{COD}} /$ Total $_{\text {COD }}$ ) promoted a decay in methane production, attaining almost null production. All the other pulses $(9,12$ and $15 \mathrm{gCOD}_{\text {oil }} / \mathrm{L}_{\text {reactor }}$ ) at lower oily waste concentrations had a positive effect in the methane production.

In Table 3 is presented the percentage of biomethanation calculated for each set of oil concentration added as a pulse, which corresponded to the percentage of methane produced relative to the theoretical biochemical methane potential.

Table 3 - Concentration of oily waste inside the reactors after feeding pulse $\left(\mathrm{gCOD}_{\mathrm{oi}} / \mathrm{L}_{\mathrm{reactor}}\right)$ and the percentage of biomethanation achieved due to each set of oil pulse concentration (adapted from previous results presented in Neves et al., 2009a).

\begin{tabular}{|c|c|c|c|c|c|c|c|}
\hline \multirow[t]{2}{*}{ Day (pulse) } & \multirow{2}{*}{$\frac{\mathrm{R} 1}{\substack{\mathrm{gCOD}_{\text {oil }} / \\
\mathrm{L}_{\text {reactor }}}}$} & \multicolumn{2}{|r|}{ R2 } & \multicolumn{2}{|r|}{ R3 } & \multicolumn{2}{|r|}{ R4 } \\
\hline & & $\begin{array}{c}\mathrm{gCOD}_{\text {oil }} / \\
\mathrm{L}_{\text {reactor }}\end{array}$ & $\begin{array}{l}\text { Biomethanation } \\
\text { (\%) (average } \pm \text { SD) }\end{array}$ & $\begin{array}{l}\mathrm{gCOD}_{\text {oil }} / \\
\mathrm{L}_{\text {reactor }}\end{array}$ & $\begin{array}{l}\text { Biomethanation } \\
\text { (\%) (average } \pm \text { SD) }\end{array}$ & $\begin{array}{l}\mathrm{gCOD}_{\text {oil }} / \\
\mathrm{L}_{\text {reactor }}\end{array}$ & $\begin{array}{l}\text { Biomethanation } \\
(\%) \text { (average } \pm \text { SD) }\end{array}$ \\
\hline 148 & 0 & 9 & $\approx 100$ & 12 & $79 \pm 15$ & 15 & $51 \pm 18$ \\
\hline 168 & 0 & 9 & & 12 & & 15 & \\
\hline 176 & 0 & 9 & & 12 & & 15 & \\
\hline 183 & 0 & 9 & & 12 & & 15 & \\
\hline 190 & 0 & 9 & & 12 & & 15 & \\
\hline 197 & 0 & 9 & & 12 & & 15 & \\
\hline 204 & 0 & 12 & $93 \pm 12$ & 15 & $59 \pm 7$ & 18 & NP \\
\hline 211 & 0 & 12 & & 15 & & 0 & \\
\hline 218 & 0 & 12 & & 15 & & 0 & \\
\hline 225 & 0 & 12 & & 15 & & 0 & \\
\hline
\end{tabular}

NP, almost null production, inhibition detected. SD, standard deviation. 


\subsection{LCFA analysis in first and second experiments}

Analyses of the fed wastes revealed that LCFA content represented 3, 4 and $77 \%$ of the total COD in cow manure, food waste and in the oily waste, respectively (Table 1 ). The main contribution of oily waste added to the reactors in terms of LCFA was C18:1 (43.2 $\pm 0.4 \%)$, followed by C18:2 (38.3 $\pm 0.5 \%)$ and $\mathrm{C} 16: 0(12.5 \pm 0.1 \%)$. The oily waste pulses led to an increase of LCFA content in the reactors.
LCFA were analysed in samples collected after each oil addition, once a day, in all the four or five subsequent days. No LCFA were detected in the liquid phase. In less than $24 \mathrm{~h}$ an exclusive detection of these compounds onto the solid matrix was observed (Fig. 1).

The results obtained from R1 solid matrix, showed that LCFA content was constant during the experiment, with $9 \pm 3$ gCOD-C16:0/kgTS and $3 \pm 1$ gCOD-C18:0/kgTS. The anaerobic co-digestion of cow manure and food waste
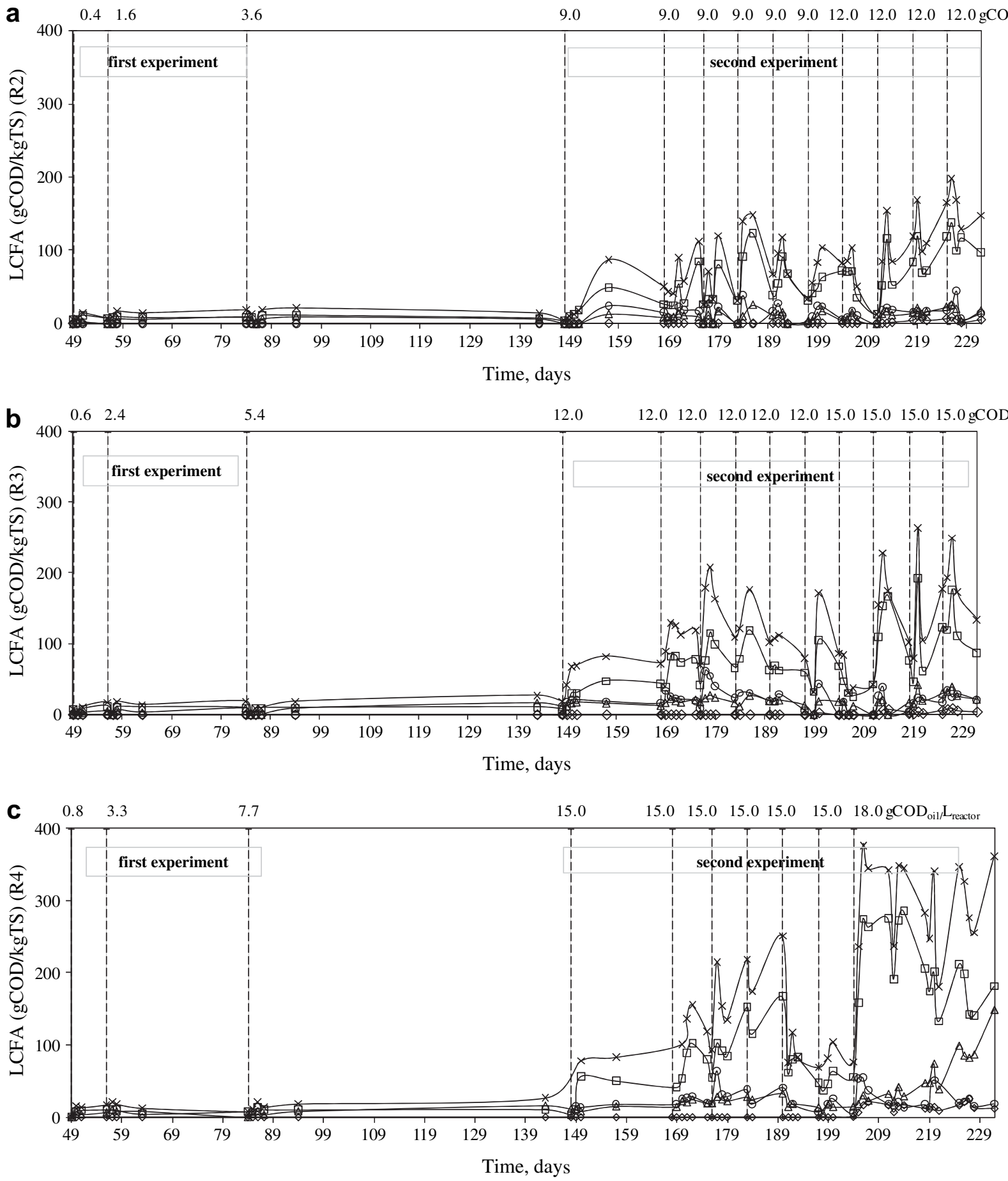

Fig. 1 - Biomass-associated LCFA (gCOD/kgTS) in R2 (a), R3 (b) and R4(c). (- $\diamond-$ C14:0; - $\square-$ C16:0; - $\triangle$ - C18:0; - - C18:1; -x- Total LCFA) [Indication of reactor COD after oil addition is depicted in each graph]. 
accomplished a reduction of 36 and $80 \%$ in C16:0 and C18:0, respectively. The acids $\mathrm{C} 18: 1$ and C18:2 corresponded to $36 \%$ and $18 \%$ of the total LCFA detected in food waste, but were never detected in R1.

In the oily waste, linoleic acid (C18:2) represented $38 \%$ of total LCFA. However, this acid was never detected in the analysed solid samples in any reactor, suggesting that its conversion in shorter chain acids was faster and easier when compared to others LCFA.

In the first experiment the maximum level of COD-LCFA accumulation detected was 25 gCOD-LCFA/kgTS, composed of $\mathrm{C} 16: 0$ and C18:0. With no statistical differences between R2, R3 and R4, using ANOVA $(P=0.51$ for $C 16: 0, P=0.30$ for $C 18: 0$, and $P=0.56$ for $\mathrm{C} 16: 0+\mathrm{C} 18: 0)$.

Analysing the results of the first experiment it is concluded that the co-digestion system, cow manure-food waste, could endorse higher lipid content. Therefore, in the second experiment the amount of oil added was higher and, therefore, higher LCFA concentrations were detected (Fig. 1).

For the pulse of $9 \mathrm{gCOD}_{\text {oil }} / \mathrm{L}_{\text {reactor, }}$ with the exception of $\mathrm{C} 16: 0$, all the other detected acids were about zero after 7 days, indicating that the time to degrade the accumulated LCFA fed as pulse was attained between pulses, and justifying the values close to $100 \%$ biomethanation achieved in this set of pulses. It should be noticed that $\%$ of biomethanation refers to the obtained methane after the oil addition, in comparison to the theoretical methane yield of the added oil.

It is important to highlight the consistent behaviour in terms of individual LCFA of the R2 and R3 response to several pulses of $12 \mathrm{gCOD}_{\text {oil }} / \mathrm{L}_{\text {reactor }}$ and $15 \mathrm{gCOD}_{\text {oil }} / \mathrm{L}_{\text {reactor. The }}$ increase from 12 to $15 \mathrm{gCOD}_{\text {oil }} / \mathrm{L}_{\text {reactor }}$ did not change the LCFA patterns, being the major acid detected palmitic acid (C16:0) representing $72 \pm 13 \%$ of the total LCFA detected.

The highest amount of LCFA adsorbed/accumulated onto the solid matrix ranged from $61 \%$ to $77 \%$ of the total LCFA fed as a pulse, with the lowest value attained at a pulse of $9 \mathrm{gCOD}_{\text {oil }} / \mathrm{L}_{\text {reactor }}$ and the highest when the feeding corresponded to $18 \mathrm{gCOD}_{\text {oil }} / \mathrm{L}_{\text {reactor. }}$ As mentioned before, accumulation of LCFA onto solids is a well known phenomenon. For instance, Petruy and Lettinga (1997) also reported that 70\% of lipids were adsorbed by granular sludge, within approximately one day.

C16:0 was always the major detected LCFA adsorbed/ accumulated onto the solid matrix and achieved higher concentrations than the ones corresponding to the influent.
This suggests that palmitic acid was also in this case a major intermediate from the conversion of C16:1, C18:0, C18:1 and C18:2, as reported by other authors (Lalman and Bagley, 2000; Pereira et al., 2002; Salminen et al., 2001). Jeganathan et al. (2006) reported that when treating complex oily wastewater in upflow anaerobic sludge blanket reactors, although attaining COD removal efficiencies of $80 \%$, reactor failure was detected after high organic loading rate due to the fat accumulation onto the biomass, which was identify mainly as C16:0 (>60\%), whereas, the fed LCFA contained only $30 \%$ C16:0 and $50 \%$ of C18:0.

The conversion between unsaturated and saturated LCFA is not yet clear. From the Gibbs free energy values the hydrogenation of the double bond of oleate to form stearate followed by a first step of b-oxidation is more reasonable to occur than the direct b-oxidation of oleate (C18:1) to palmitoleate (C16:1) (Sousa, 2007). However the reason why palmitate is not further degraded and tends to accumulate in reactors fed with lipids is a question that remains unclear.

Nielsen and Ahring (2006) observed that an addition of $2.0 \mathrm{~g}$ oleate/L ( $5.8 \mathrm{gCOD} / \mathrm{L})$ to reactors fed with a mixture of cattle and pig manure led to an inhibition illustrated by an instant drop in the methane production, although the reactors performance recovered after a period of time. In the present work the oleate COD present in the pulse feed of $18 \mathrm{gCOD}_{\text {oil }} /$ $\mathrm{L}_{\text {reactor }}$ was equivalent to $5.9 \mathrm{gCOD} / \mathrm{L}_{\text {reactor, }}$ comparable to the amount reported by the former authors, with the exception that C18:1 acid was within a complex mixture of LCFA, and no recover was detected in $\mathrm{R} 4$ after 30 days.

The major acid identified onto the solid matrix was C16:0 at 273 gCOD-C16:0/kgTS in R4 (Fig. 1 (c)). However, an overall decrease in the accumulation of C16:0 was observed, which became more evident in the last days of operation, to values near the ones detected for the other pulses. Nevertheless, the methane production did not recover and conversely to the other reactors, stearate (C18:0) concentration increased, even without any extra addition of oily waste. At the end of the experiment, this acid was $41 \%$ at a concentration of 140 gCODC18:0/kgTS jointly with the 180 gCOD-C16:0/kgTS corresponding to $50 \%$ of the detected acids.

The accumulation of C18:0 in the presence of high concentrations of $\mathrm{C} 16: 0$ has been reported in fat degradation in rumen metabolism (Van Nevel and Demeyer, 1995, 1996). Linoleic and oleic acids in the feeding (Table 2) seemed to be first converted to the intermediate palmitic acid and, in the
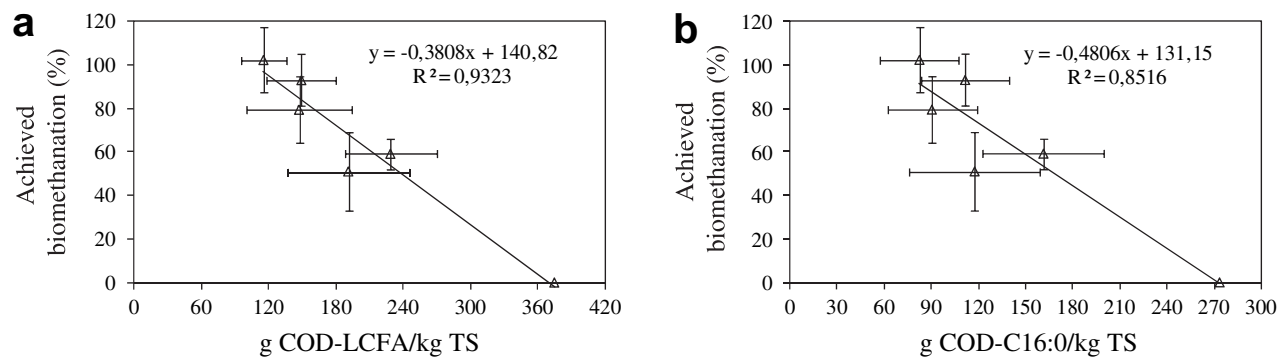

Fig. 2 - Influence of maximum transient accumulation of LCFA (a) and palmitic acid (b) in the achieved biomethanation (\%), for all applied pulses. Values represent the average of 6 pulses of $9 \mathrm{gCOD}_{\text {oil }} / \mathrm{L}_{\text {reactor }}(\mathrm{R} 2), 10$ pulses of $12 \mathrm{gCOD}$ oil $/ \mathrm{L}_{\text {reactor }}$ $(R 2+R 3), 10$ pulses of $15 \mathrm{gCOD}_{\mathrm{oil}} / \mathrm{L}_{\text {reactor }}(\mathrm{R} 3+\mathrm{R} 4)$ and 1 pulse of $18 \mathrm{gCOD}_{\mathrm{oil}} / \mathrm{L}_{\text {reactor }}(\mathrm{R} 4)$. Bars represent the standard deviation. 
last 10 days of operation, an higher proportion of stearic/palmitic acid was detected, suggesting a different dynamics of intermediates accumulation during the operation in R4. Although reactor R4 was not like a rumen systems, some parallelism can be done between the two processes. Unsaturated fatty acids have relatively short half-lives in ruminal contents because they are rapidly hydrogenated by microorganisms to more saturated end products (Harfoot and Hazlewood, 1988). The extent to which biohydrogenation of double bonds occurs is variable and its optimum pH is 6.5 (Van Nevel and Demeyer, 1995). R4 was the only reactor that presented altered patterns after day 204. The soluble COD and the volatile fatty acids increased considerably, and $\mathrm{pH}$ values decreased attaining 6.5 as previous demonstrated in Neves et al. (2009a).

Methane production was hampered when the total adsorbed/accumulated LCFA attained 375 gCOD-LCFA/kgTS, which occurred after the $18 \mathrm{gCOD}_{\text {oil }} / \mathrm{L}_{\text {reactor }}$ pulse. Furthermore, a clear linear negative correlation was observed between the achieved \% of biomethanation and the highest transient solids-associated LCFA detected in all the pulses (Fig. 2a). From all the LCFA detected, palmitic acid (C16:0) was the main responsible for the observed decay in the methane production (Fig. 2b).

According to these results, the quantification of solidsassociated LCFA or C16:0 allows the prediction of the biomethanation \%, suggesting to be key indicators of biomethanation failure. Threshold values for LCFA and C16:0 accumulation onto the solid matrix, of about 180-220 gCODLCFA/kgTS and 120-150 gCOD-C16:0/kgTS, should not be surpassed in order to prevent failure of the system.

These value are however lower than the optimal reported by Pereira et al. (2004), for the amount of biomass-associated LCFA - 1000 gCOD-LCFA/kgVS-, that could be degraded in batch assays at a maximal rate around 250 gCOD-LCFA/ kgVS day. However, in that work, the value refers to an indirect measurement of LCFA associated to the cells that was degraded to methane in batch vials, and the VS refers to the cells, free of LCFA. In the present work, LCFA are measured by direct extraction and quantification, and the TS refer to the bulk solids content that includes cells, fibers and biomassassociated LCFA.

\section{Conclusions}

The results of these experiments demonstrate that co-digestion of cow manure/food waste in a continuous stirred tank reactor with 15 days hydraulic retention time, presents a sufficient buffer capacity to endorse lipids fluctuations, up to concentrations of $7.7 \mathrm{gCOD}_{\text {oil }} / \mathrm{L}_{\text {Reactor }}\left(55 \% \mathrm{Oil}_{\mathrm{COD}} / \mathrm{Total}_{\mathrm{COD}}\right)$, maintaining an efficient overall reactor performance and stability, when the total COD fed is constant. The same codigestion system can endure recurrent pulses of oil (once

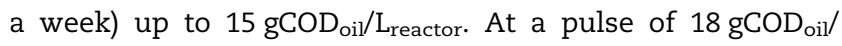
$\mathrm{L}_{\text {reactor }}$ reactor failure was persistent. Negative linear correlations between the achieved biomethanation \% and the solidassociated LCFA or palmitic acid, allowed to establish threshold values 180-220 gCOD-LCFA/kgTS and 120150 gCOD-C16:0/kgTS, respectively, that should not be surpassed in order to prevent reactor failure. The approach of occasionally adding lipids to the anaerobic co-digestion can be a feasible option to biodegrade fats/greases, recovering the methane potential of these substrates.

\section{Acknowledgements}

Fundação para a Ciência e Tecnologia (FCT) and Fundo Social Europeu (FSE) are acknowledged for the financial support given to Lúcia Neves through the grant SFRH/BD/18174/2004.

\section{R E F E R E N C E S}

Ahring, B.K., 2003. Perspectives for anaerobic digestion. In: Ahring, B.K. (Ed.), Biomethanation I. Advances in Biochemical Engineering/Biotechnology, vol. 81. Springer, Berlin, pp. 1-30.

Alves, M.M., Pereira, M.A., Sousa, D.Z., Cavaleiro, A.J., Picavet, M., Smidt, H., Stams, A.J.M., 2009. Waste lipids to energy: how to optimize methane production from long-chain fatty acids (LCFA) - minireview (early view). Microbial Biotechnology 2 (5), 538-550.

Angelidaki, I., Ahring, B.K., 1992. Effects of free long-chain fatty acids on thermophilic anaerobic digestion. Applied Microbiology and Biotechnology 37, 1423-1428.

APHA, AWWA, WPCF, 1989. Standard Methods for the Examination of Water and Wastewater, 17th ed. American Public Health Association, Washington D.C.

Bouallagui, H., Torrijos, M., Godon, J.J., Moletta, R., Ben Cheikh, R., Touhami, Y., Delgenes, J.P., Hamdi, M., 2004. Two-phase anaerobic digestion of fruit and vegetable wastes: bioreactors performance. Biochemical Engineering Journal 21, 193-197.

Braun, R., Brachtl, E., Grasmug, M., 2003. Codigestion of proteinaceous industrial waste. Applied Biochemistry and Biotechnology 109, 139-154.

Carucci, G., Carrasco, F., Trifoni, K., Majone, M., Beccari, M., 2005. Anaerobic digestion of food industry wastes: effect of codigestion on methane yield. Journal of Environmental Engineering 131 (7), 1037-1045.

Cirne, D.G., Paloumet, X., Björnsson, L., Alves, M.M., Mattiasson, B., 2007. Anaerobic digestion of lipid-rich waste - effects of lipid concentration. Renewable Energy 32 (6), 965-975.

Colleran, E., Concannon, F., Goldem, T., Geoghegan, F., Crumlish, B., Killilea, E., Henry, M., Coates, J., 1992. Use of methanogenic activity tests to characterize anaerobic sludges, screen for anaerobic biodegradability and determine toxicity thresholds against individual anaerobic trophic groups and species. Water Science and Technology 25, 31-40.

Hanaki, K., Matsuo, T., Nagase, M., 1981. Mechanisms of inhibition caused by long chain fatty acids in anaerobic digestion process. Biotechnology and Bioengineering 23, 1591-1610.

Hansen, K.H., Ahring, B.K., Raskin, L., 1999. Quantification of syntrophic fatty acid-b-oxidizing bacteria in a mesophilic biogas reactor by oligonucleotide probe hybridization. Applied and Environmental Microbiology 65, 4767-4774.

Harfoot, C.G., Hazlewood, G.P., 1988. Lipid metabolism in the rumen. In: Hobson, P.N. (Ed.), The Rumen Microbial Ecosystem. Elsevier Applied Science, London, pp. 285-322.

Hill, D.T., 1984. Methane productivity of the major animal waste types. Transactions of the ASAE 27, 530-534.

Hwu, C.-S., Tseng, S.-K., Yuan, C.-Y., Kulik, Z., Lettinga, G., 1998. Biosorption of long-chain fatty acids in UASB treatment process. Water Research 32, 1571-1579. 
Jeganathan, J., Nakhala, G., Bassi, A., 2006. Long-term performance of high rate anaerobic reactors for the treatment of oily wastewater. Environmental Science and Technology 40, 6466-6472.

Kim, H.-W., Han, S.-K., Shin, H.-S., 2004. Anaerobic co-digestion of sewage sludge and food waste using temperature-phased anaerobic digestion process. Water Science and Technology 50 (9), 107-114.

Lalman, J., Bagley, D.M., 2000. Anaerobic degradation and inhibitory effects of linoleic acid. Water Research 34, 4220-4228.

Lindboe, H.H., Gregersen, K.H., Tafdrup, S., Jacobsen, O.G., Christensen, J.G., 1995. Progress Report on the Economy of Centralized Biogas Plants. Danish Energy Agency Biomass Section, Copenhagen, Denmark.

Li, Y.Y., Sasaki, H., Yamashita, K., Seki, K., Kamigochi, I., 2002. High-rate methane fermentation of lipid-rich food wastes by a high-solids codigestion process. Water Science and Technology 45, 143-150.

Miranda, L.A.S., Henriques, J.A.P., Monteggia, L.O., 2006. Performance of UASB and DAEB reactors in the anaerobic digestion of synthetic wastewater containing sodium oleate and sodium stearate. Water Science and Technology 54 (2), 127-133.

Möller, H.B., Sommer, S.G., Ahring, B.K., 2004. Methane productivity of manure, straw and solid fractions of manure. Biomass and Bioenergy 26 (5), 485-495.

Neves, L., Oliveira, R., Alves, M.M., 2004. Influence of inoculum activity on the bio-methanization of a kitchen waste under different waste/inoculums ratios. Process Biochemistry 39, 2019-2024.

Neves, L., Oliveira, R., Alves, M.M., 2009a. Co-digestion of cow manure, food waste and intermittent input of fat. Bioresource Technology 100 (6), 1957-1962.

Neves, L., Pereira, M.A., Mota, M., Alves, M.M., 2009b. Detection and quantification of long chain fatty acids in liquid and solid samples and its relevance to understand anaerobic digestion of lipids. Bioresource Technology 100, 91-96.

Nielsen, H.B., Ahring, B.K., 2006. Responses of the biogas process to pulses of oleate in reactors treating mixture of cattle and pig manure. Biotechnology and Bioengineering 95, 96-105.

Official Methods of Analysis, 2007. Official Method 2003.05, 18th ed. AOAC International, Gaithersburg, MD.
Paavola, T., Syväsalo, E., Rintala, J., 2006. Co-digestion of manure and biowaste according to the EC animal by-products regulation and Finnish national regulations. Water Science and Technology 53 (8), 223-231.

Pereira, M.A., Pires, O.C., Mota, M., Alves, M.M., 2002. Anaerobic degradation of oleic acid by suspended and granular sludge: identification of palmitic acid as a key intermediate. Water Science and Technology 45, 139-144.

Pereira, M.A., Pires, O.C., Mota, M., Alves, M.M., 2005. Anaerobic biodegradation of oleic and palmitic acids: evidence of mass transfer limitations caused by the accumulation of LCFA onto the anaerobic sludge. Biotechnology and Bioengineering 92, 15-23.

Pereira, M.A., Sousa, D.Z., Mota, M., Alves, M.M., 2004. Mineralization of LCFA associated to anaerobic sludge: kinetics, transport limitations, enhancement of methanogenic activity and effect of VFA. Biotechnology and Bioengineering 88 (4), 502-510.

Petruy, R., Lettinga, G., 1997. Digestion of a milk-fat emulsion. Bioresource Technology 61, 141-149.

Rinzema, A., Boone, M., van Knippenbeg, K., Lettinga, G., 1994. Bactericidal effect of long chain fatty acids in anaerobic digestion. Water Environment Research 66, 40-49.

Salminen, E., Einola, J., Rintala, J., 2001. Characterization and anaerobic batch degradation of materials accumulating in anaerobic digesters treating poultry slaughterhouse waste. Environmental Technology 33, 577-585.

Sousa, D.Z., 2007. Ecology and Physiology of Anaerobic Microbial Communities that Degrade Long Chain Fatty Acids. PhD thesis, Braga, Portugal, University of Minho. https:// repositorium.sdum.uminho.pt/handle/1822/6287.

Van Nevel, C.J., Demeyer, D.I., 1995. Lipolysis and biohydrogenation of soybean oil in the rumen in vitro: inhibition by antimicrobials. Journal of Dairy Science 78, 2797-2806.

Van Nevel, C.J., Demeyer, D.I., 1996. Influence of pH on lipolysis and biohydrogenation of soybean oil by rumen contents in vitro. Reproduction, Nutrition, Development 36, 53-63.

Vavilin, V.A., Jonsson, S., Ejlertsson, J., Svensson, B.H., 2006. Modelling MSW decomposition under landfill conditions considering hydrolytic and methanogenic inhibition. Biodegradation 17 (5), 389-402.

Weiland, P., 2004. Anaerobic waste digestion in Germany-status and recent development. Biodegradation 11 (6), 415-421. 